\title{
Assessment of microbiological contamination in the work environments of museums, archives and libraries
}

\author{
Justyna Skóra • Beata Gutarowska • Katarzyna Pielech-Przybylska • \\ Lukasz Stępień · Katarzyna Pietrzak · Małgorzata Piotrowska · Piotr Pietrowski
}

Received: 10 July 2014 / Accepted: 2 March 2015/Published online: 15 March 2015

(C) The Author(s) 2015. This article is published with open access at Springerlink.com

\begin{abstract}
Museums, archives and libraries have large working environments. The goal of this study was to determine microbial contamination in these work places and estimate the influence of microclimatic parameters and total dust content on microbial contamination. In addition, research included evaluation of ergosterol concentration and fungal bioaerosol particle size distribution. Numbers of micro-organisms in the air and on the surfaces in museums were higher $\left(2.1 \times 10^{2}-7.0 \times 10^{3} \mathrm{cfu} / \mathrm{m}^{3}\right.$ and $1.4 \times 10^{2}-$ $1.7 \times 10^{4} \mathrm{cfu} / 100 \mathrm{~cm}^{2}$, respectively) than in archives and libraries $\left(3.2 \times 10^{2}-7.2 \times 10^{2} \mathrm{cfu} / \mathrm{m}^{3}\right.$ and $8.4 \times$ $10^{2}-8.8 \times 10^{2} \mathrm{cfu} / 100 \mathrm{~cm}^{2}$, respectively). The numbers of micro-organisms detected in the tested museums, archives and libraries did not exceed occupational exposure limits proposed by Polish Committee for the Highest Permissible Concentrations and
\end{abstract}

J. Skóra $(\varangle)$ · B. Gutarowska · K. Pielech-Przybylska · K. Pietrzak · M. Piotrowska

Institute of Fermentation Technology and Microbiology, Lodz University of Technology, 171/173 Wólczańska St, 90-924 Lodz, Poland

e-mail: justyna-skora@wp.pl

Ł. Stępień

Institute of Plant Genetics, Polish Academy of Sciences, 34 Strzeszyńska St, 60-479 Poznan, Poland

P. Pietrowski

Department of Protective Equipment, Central Institute for Labour Protection - National Research Institute, 48

Wierzbowa St, 90-133 Lodz, Poland
Intensities of Noxious Agents at the Workplace. The concentrations of respirable and suspended dust in museum storerooms were 2-4 times higher than the WHO-recommended limits. We found a correlation between microclimatic conditions and numbers of micro-organisms in the air in the tested working environments. In addition, a correlation was also found between ergosterol concentration and the number of fungi in the air. Fungi were the dominant microorganisms in the working environments tested. Particles within the dominant fractions of culturable fungal aerosols sampled from museum storerooms had aerodynamic diameters between 1.1 and $2.1 \mu \mathrm{m}$.

Keywords Micro-organisms at workplaces . Ergosterol - Bioaerosol · Microclimatic parameters . Museum $\cdot$ Archive $\cdot$ Library

\section{Introduction}

Museums, archives and libraries are institutions that are crucial for preserving cultural heritage all over the world. Given the number of such institutions, they also contribute from 0.5 to $2.6 \%$ of total employment (based on the data of the Polish Central Statistical Office [GUS] 2012), thus constituting a significant proportion of working environments (for archivists, curators, librarians, conservators, storeroom workers and office staff). Previous microbiological analyses in museums, libraries and archives have shown high 
microbial air contamination, which may pose a danger to historical objects and also to staff (Gysels et al. 2004; Zielińska-Jankiewicz et al. 2008; Mesquita et al. 2009; Karbowska-Berent et al. 2011; Skóra et al. 2012).

Health threats in these institutions arise due to the inhalation of the micro-organism-contaminated air and by handling, cleaning and conserving items many of which are mould infested. Wiszniewska et al. (2009) identified allergy to fungi in $31 \%$ of staff working at the National Museum in Warsaw (number of subjects studied $\mathrm{n}=103$ ). Moreover, workers' exposure to micro-organisms may have additional consequences such as infections and mycotoxicoses. Mycotoxins produced by fungi (e.g. Aspergillus flavus, A. parasiticus, A. versicolor, Penicillium chrysogenum, P. expansum, Stachybotrys chartarum) often isolated from museums, libraries and archive facilities are known to have harmful effects (Halstensen 2008; Eduard 2009). Mycotoxins and microbial volatile organic compounds (MVOC's) might constitute aetiological factors in sick building syndrome (SBS) (Korpi et al. 2009).

Comprehensive data describing the problem of microbial contamination in museums, libraries and archive rooms are not available. Obtaining such data is a difficult task due to the varying conditions of each institution (different collections of objects, microclimatic parameters, concentration of dust), which may impact the levels and types of micro-organisms. The goal of the present study was to determine microbial contamination in the above institutions. The study was designed to answer the following questions: Do museums, archives and libraries have similar levels and types of microbial contamination? What influence do temperature, relative humidity and concentration of dust in the air have on micro-organism numbers within these premises? Is ergosterol a good measure of fungal contamination in museums, archives and libraries? What are the risks to workers inhaling bioaerosol within these premises?

\section{Materials and methods}

\subsection{Description of the studied rooms}

Microbiological contamination was analysed in four museums, two libraries and two archives (total of 22 rooms) located in Poland. Descriptions of tested rooms are presented in Table 1. The temperature and humidity of the air in the tested rooms were determined using a PWT-401 hygrometer (Elmetron, Poland). Dust content was measured using a DustTrak DRX Aerosol Monitor (model 8533, TSI, USA). Simultaneously, measurements of size-segregated mass fraction concentrations corresponding to PM2.5 (diameter less than $<2.5 \mu \mathrm{m})$, PM10 $(<10 \mu \mathrm{m})$ size fractions and total dust were taken.

\subsection{Determination of microbiological contamination of air and surfaces}

Air Sampler MAS-100 Eco (Merck, Germany) was used for air sampling. Air samples of 50 and $100 \mathrm{~L}$ were taken on DG18 agar medium (Dichloran Glicerol Selective Medium, Merck, Germany) and MEA medium (Malt Extract Agar, Merck, Germany) with chloramphenicol $(0.1 \%)$ for determining total fungal number (including xerophilic and hydrophilic fungi) and on a TSA medium (Tryptic Soy Agar, Merck, Germany) with nystatin $(0.2 \%)$ for determining total bacterial number. Air samples were collected in two sequential repetitions on each medium, in three locations in each room using a single sampler. Samples were collected in winter 2011 (between November and February), during one working day, when staff were performing routine activities in the tested museums, archives and libraries.

Office rooms were analysed as internal backgrounds for each site (three repetitions on each medium), and the atmospheric air outside each building site was analysed as the external background (three repetitions on each medium). Bioaerosol particle sizes were determined from samples collected in rooms with the highest level of fungal contamination (storerooms in Museum II), since they might pose the greatest health risk to employees. Samples for determining particle size distribution of fungal bioaerosol were collected from selected museum storerooms, an office room (internal background) and atmospheric air (external background), using a six-stage Andersen sampler (model WES-710, Westech Instruments, UK). Samples were collected over $5 \mathrm{~min}$ (141.5 1 of air) on MEA medium with chloramphenicol $(0.1 \%)$ in two repetitions on each medium in three places in room.

Samples from surfaces were collected using Envirocheck $^{\circledR}$ plates (Merck, Germany) on TSA medium 


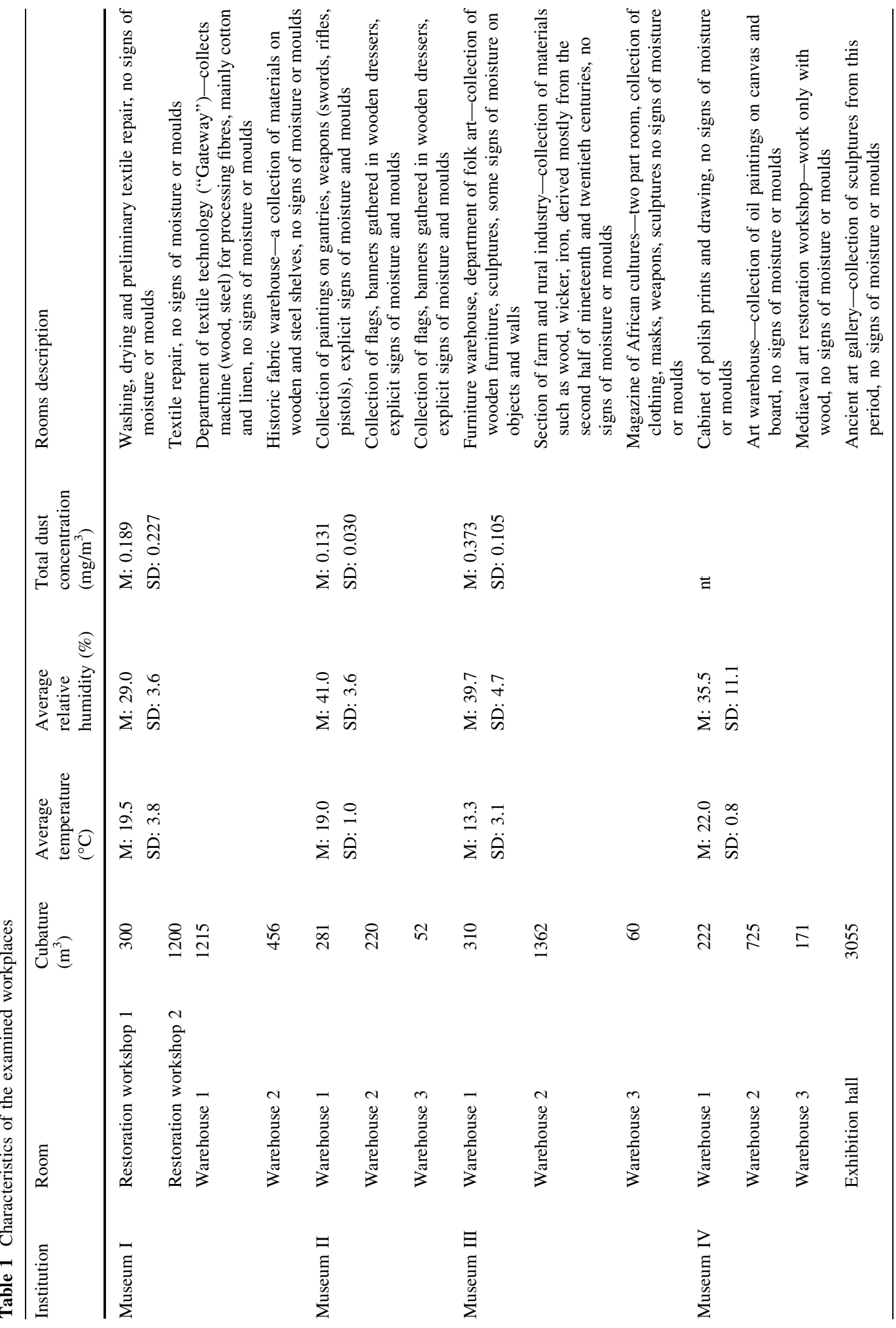




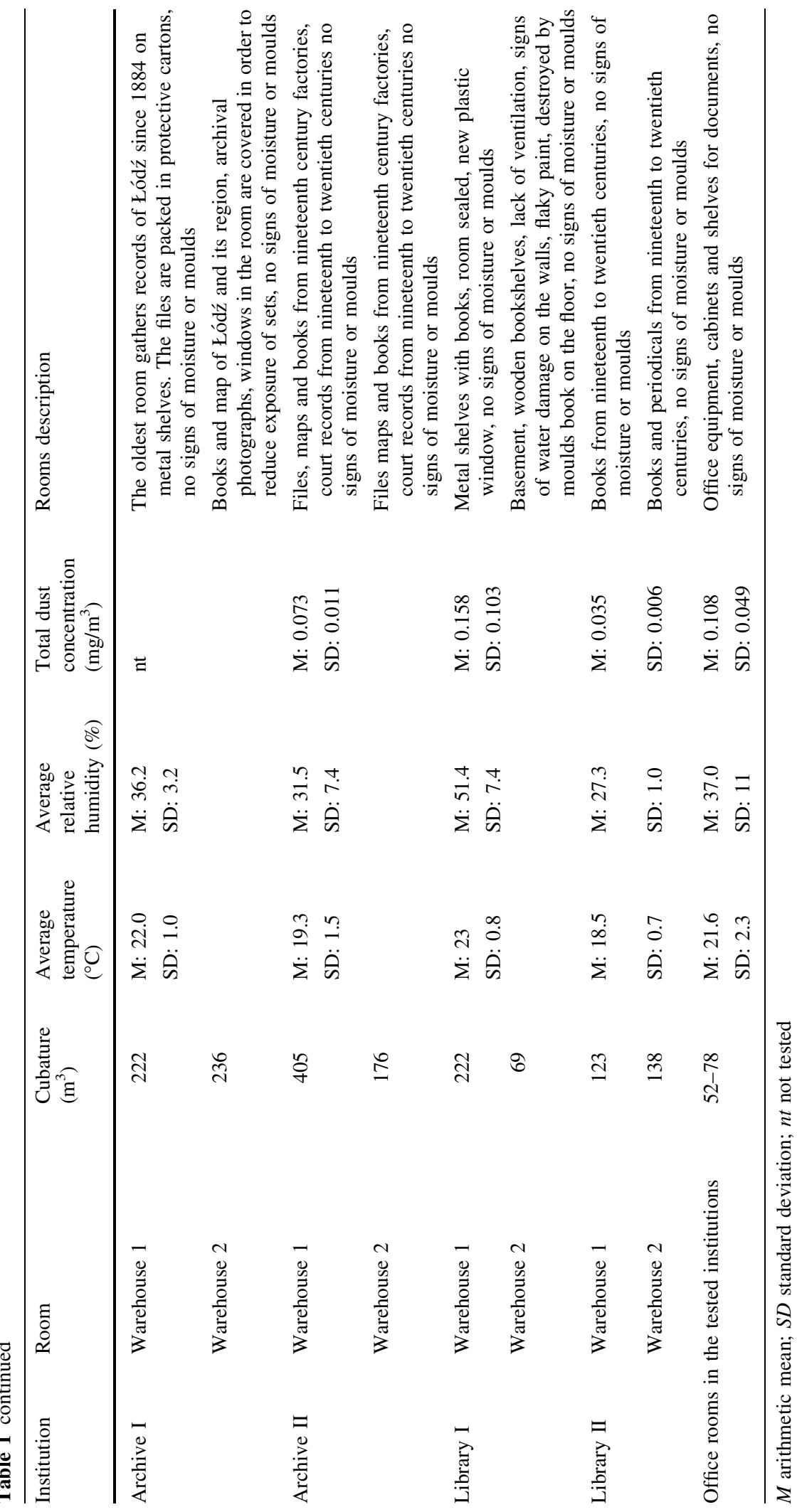


with neutralizers (for bacteria) and on Sabouraud medium (for fungi). For highly contaminated surfaces, the traditional swab method was applied, using saline solution $(0.85 \% \mathrm{NaCl})$, swabs, metal frames of $25 \mathrm{~cm}^{2}$ surface area and the media described above. Samples were collected from 3 to 5 surfaces (furniture, walls, books and stored objects) on each medium, in every room (total number of samples in a given institution: 10-15). The samples were incubated at $30 \pm 1{ }^{\circ} \mathrm{C}$ for $48 \mathrm{~h}$ (bacteria) or at $27 \pm 1{ }^{\circ} \mathrm{C}$ for 5 days (fungi). After incubation, the colonies were counted, and the results were expressed in $\mathrm{cfu} / \mathrm{m}^{3}$ (air) or $\mathrm{cfu} / 100 \mathrm{~cm}^{2}$ (surfaces). The final results are presented as the arithmetic mean of all repetitions.

\subsection{Identification of bacteria and yeasts}

All bacteria and yeasts isolated from samples were transferred onto individual culture plates. Following this, they were macroscopically and microscopically characterized using Gram-staining, catalase test and oxidase test (Microbiologie Bactident Oxydase, Merck, Germany). Next, isolates with the same morphology and biochemical features were grouped into strains and identified using API tests (BioMérieux, France): API $50 \mathrm{CH}$, API STAPH and API $20 \mathrm{NE}$ (for bacteria) and API C AUX (for yeasts). Identified bacteria were genetically confirmed using the $16 \mathrm{~S}$ rRNA gene nucleotide sequence (Jensen et al. 1993).

Isolated filamentous fungi were cultured on CYA (Czapek Yeast Extract Agar, Difco, USA) and YES medium (yeast extract with supplements) and visually identified, macroscopically and microscopically, using taxonomic keys (Bensch et al. 2012; Frisvad and Samson 2004; Pitt and Hocking 2009; Klich 2002). Identity of moulds and yeasts was confirmed using ITS1/2 sequence of the rDNA region (White et al. 1990). Genomic DNAs were extracted using a method described previously (Stępień et al. 2011). The resulting nucleotide sequences of the studied microorganisms were analysed and compared to the sequences published in the National Center for Biotechnology Information (NCBI) database, using the BLASTN 2.2.27+ program (Zhang et al. 2000).

\subsection{Ergosterol determination}

Air samples for ergosterol determination were collected using an AirPort MD8 sampler (Sartorius,
Germany). In total, 1000-L samples (six repetitions) were collected on sterile gelatine filters (pore diameter $0.3 \mu \mathrm{m}$, Sartorius, Germany). Ergosterol was quantified based on Miller and Young's (1997) method using a modified analytical procedure. Chromatographic analysis (gas chromatography with flame ionization detection-GC-FID) was carried out using a GC apparatus (Agilent 6890N HP, USA). Quantitative analysis was performed using an external standard (external calibration) method, with software from Agilent ChemStation (USA).

\subsection{Statistical analyses}

Statistical analyses were performed using STATISTICA 6.0 software (Statsoft, USA). All results were evaluated using one-way analysis of variance (ANOVA) at the 0.05 significance level. When statistical differences were detected $(p<0.05)$, means were compared by the post hoc Fisher's test at 0.05 significance level.

Linear regression analysis was used to determine the effect of air humidity and temperature and total dust on microbiological contamination of the air and surfaces in tested buildings. Linear regression analysis was also used to determine the effect of air and surface microbiological contamination on ergosterol concentration in the air. The significance tests were performed at the 0.05 significance level using Guilford's correlation scale (Stanisz 2006).

\section{Results}

The number of micro-organisms in the air in museums averaged from $2.1 \times 10^{2}$ to $7.0 \times 10^{3} \mathrm{cfu} / \mathrm{m}^{3}$ and on the surfaces from $1.4 \times 10^{2}$ to $1.7 \times 10^{4} \mathrm{cfu} / 100 \mathrm{~cm}^{2}$ (Figs. 1,2). Museum IV had the lowest level of air and surface microbiological contamination (high standards of hygiene, monitoring system for microclimatic parameters, museum of national rank). The highest concentration of bacteria was found in the air of Museum III, whose collections consist of folk culture objects (mainly made of wood and fabric). The highest statistically significant $(p<0.05)$ fungal contamination was found in Museum II, a war memorial museum (collections of paintings, firearms, weapons and flags). The fungal concentration in the rooms of that museum 
Fig. 1 Mean concentration ( \pm 1 SD) of microorganisms in museums, archives and libraries, including internal (office) and external (outdoors) background. Number if samples $(\mathrm{N}=12-24)$. Limit for fungioccupational exposure limits proposed by polish committee for the highest permissible concentrations and intensities of Noxious Agents at the workplace

Fig. 2 Mean concentration ( \pm 1 SD) of microorganisms on the surface in museums, archives and libraries including internal (office) background. Number of samples $(\mathrm{N}=12-24)$
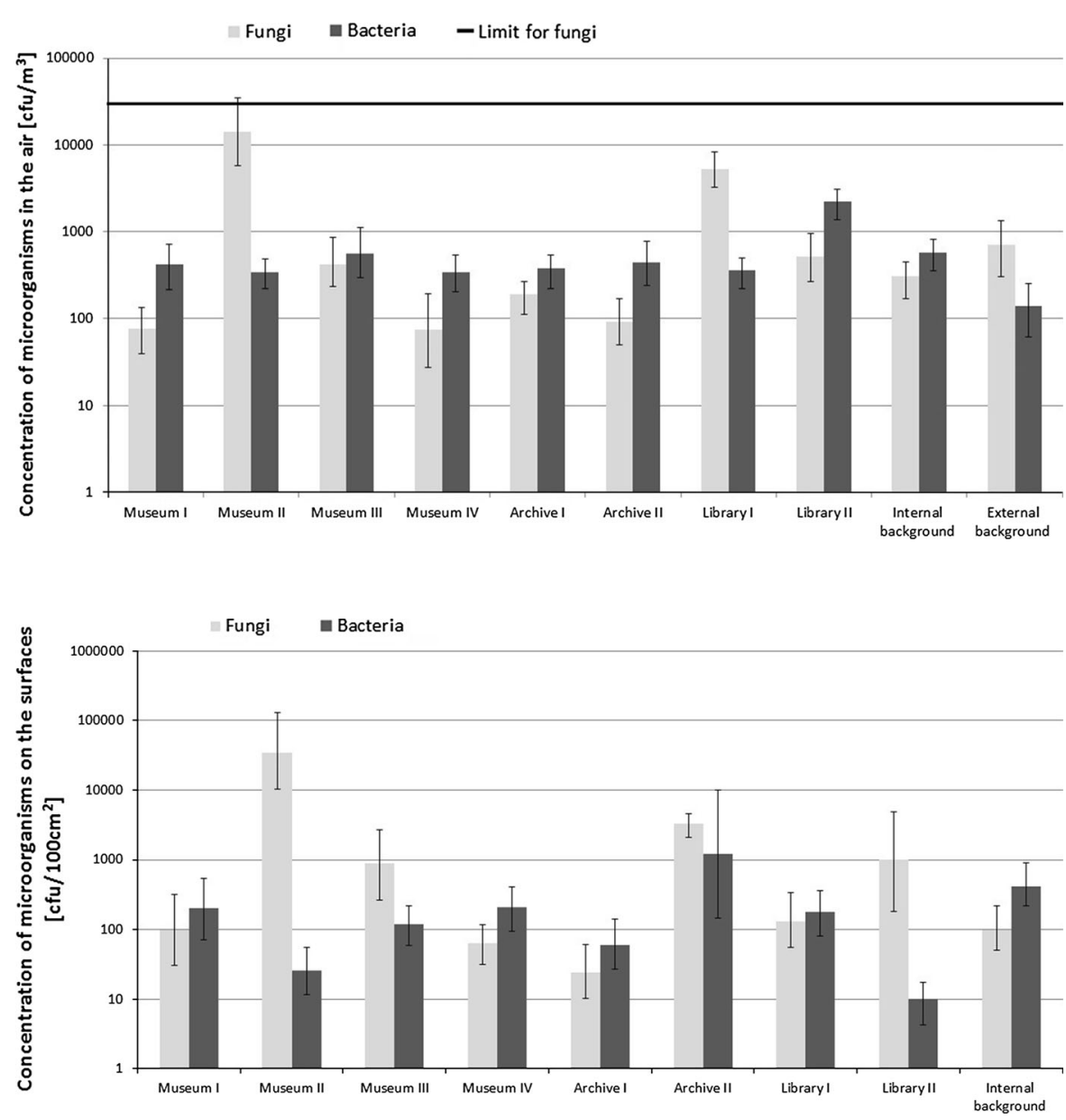

was 20 times greater than in the atmospheric air $(p<0.05)$.

The level of microbial contamination in the air of archives and libraries ranged from $4.9 \times 10^{2}$ to $5.6 \times 10^{3} \mathrm{cfu} / \mathrm{m}^{3}$, while the number of surface microorganisms was between $8.4 \times 10^{1}$ and $3.9 \times 10^{3} \mathrm{cfu} /$ $100 \mathrm{~cm}^{2}$. Amongst institutions of this type, the highest microbiological air contamination was found in Library I (rooms with signs of moisture and moulds on walls and books). The air of this library had higher concentrations of airborne fungi compared to other similar institutions $\left(5.3 \times 10^{3} \mathrm{cfu} / \mathrm{m}^{3}, p<0.05\right)$.

The number of micro-organisms on the surfaces was low, and the collected materials in most institutions did not have active microbial growth; except Museum II, Archive II had high levels of contamination on objects. However, there were no statistically significant differences in the levels of fungi (except
Museum II) and bacteria (except Archive II) on the surfaces in the tested buildings $(p>0.05)$.

The concentrations of ergosterol ranged from 0.41 to $0.69 \mathrm{ng} / \mathrm{m}^{3}$ (Fig. 3). The highest level of ergosterol was found in Museum III and Library II, which may indicate problems with fungal infestation. The lowest concentration of ergosterol $\left(0.41-0.46 \mathrm{ng} / \mathrm{m}^{3}\right)$ was found in archive rooms.

Regression analysis revealed high positive correlations between ergosterol concentrations and numbers of fungi in the air in museums $(r=0.787-0.829$, $p<0.05)$ and archives $(r=0.776-0.939, p<0.05)$. Results of regression analysis undertaken for libraries indicate a moderate influence of fungal contamination on ergosterol concentration in Library I $(r=0.482$, $p<0.05$ ); however, the significance coefficient calculated for Library II $(r=0.311, p>0.05)$ shows no correlation between the examined values. 
Fig. 3 Mean concentration $( \pm 1 \mathrm{SD})$ of ergosterol concentration in the air in tested institutions including internal (office) background. Number of samples $(\mathrm{N}=3-6)$

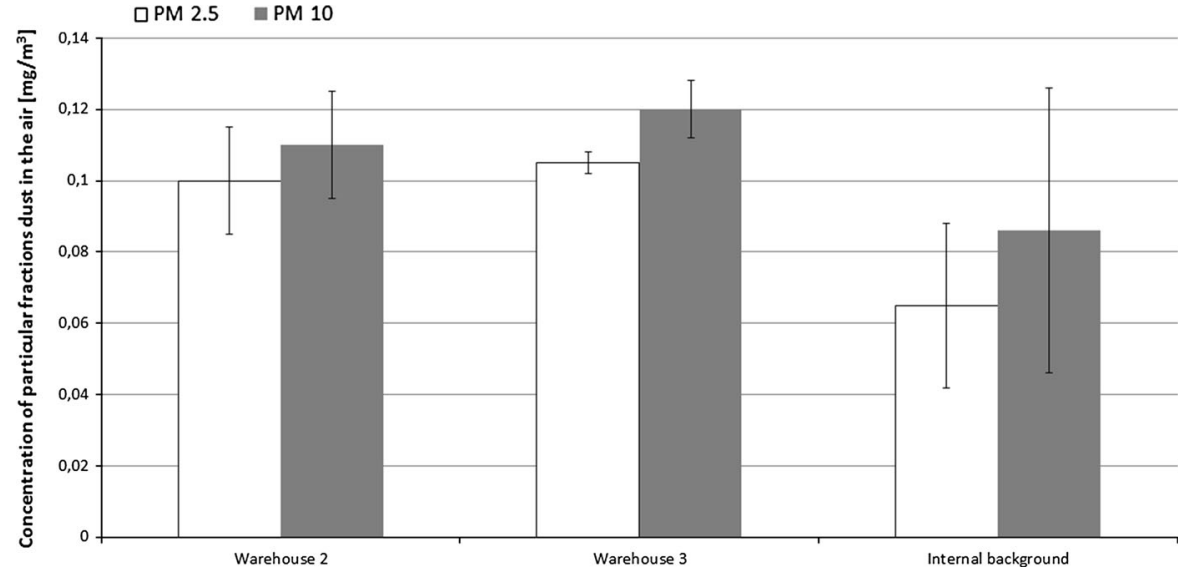

The concentration of ergosterol in the air and the number of fungi on the surfaces in two workplaces had moderate correlation: Museum I $(r=0.490$, $p<0.05)$ and Archive I $(r=0.461, p<0.05)$. All other institutions examined showed no correlation between these two parameters (significance levels $p>0.05$ ). The influence of microclimate parameters on the number of micro-organisms in the air was tested. The correlation between the temperature and number of micro-organisms in air samples was high $(r=0.610-0.863, p<0.05)$ in $7 / 8$ institutions. Regression coefficients describing the effect of air humidity on microbial concentration showed high correlations $(r=0.690-0.971, p<0.05)$ in $6 / 8$ institutions.

Significant correlations $(p<0.05)$ were also observed between microclimatic parameters and the number of surface micro-organisms in 6/8 institutions; correlation coefficient $(r)$ equalled from 0.412 to 0.890 and from 0.428 to 0.906 for temperature and humidity, respectively. No significant correlations $(p>0.05)$ were found in two institutions (Library II and Museum IV).

The impact of total dust concentrations on air microbial contamination levels was determined. In museums and libraries, linear regression results showed high correlation between these parameters. This was confirmed by high correlation coefficients, which ranged from 0.794 to $0.908(p<0.05)$ for all workplaces except Archive 1. Correlation in Archive 1 was not significant $(r=0.351, p>0.05)$.

Moreover, the concentration of respirable dust (particle diameter $<2.5 \mu \mathrm{m}$ ) in museum storerooms ranged between 0.100 and $0.105 \mathrm{mg} / \mathrm{m}^{3}$, which was higher than office rooms (internal background samples) (Fig. 4).

The dominant fraction of culturable fungal aerosol in museum storerooms had aerodynamic diameters between 1.1 and $2.1 \mu \mathrm{m}$ (fraction $\mathrm{V}$ ), and it accounted for $40-42 \%$ of the fungal bioaerosols, depending on the room. One of the storerooms (Storeroom 3) had a large contribution from fraction IV (36\%), consisting of particles with aerodynamic diameters of 2.1-3.3 $\mu \mathrm{m}$. This was also the dominant fraction culturable fungal aerosol in samples from office rooms (internal background), while the greatest percentage contribution from atmospheric air (external background) came from particles measuring 3.3-4.7 $\mu \mathrm{m}$ (fraction III) (Fig. 5).

A total of 16 bacterial strains were isolated from museum premises, 13 from archives and 13 from libraries (Table 2). Bacteria from the Micrococcus, Staphylococcus and Bacillus genera dominated each institution type, while other species of bacteria were specific to particular buildings. Qualitative composition of fungi varied in tested environments: 32 species of fungi (28 moulds and 4 yeasts) were isolated in museums, 24 species (21 moulds and 3 yeasts) in archives and 34 (32 moulds and 2 yeasts) in libraries (Table 2). The most common fungi were as follows: Aspergillus puulaaensis, Cladosporium cladosporioides, Penicillium crustosum, Rhizopus oryzae. However, there were distinct differences in air and surface fungal composition between institutions. It is worth emphasizing that 45 amongst the 89 isolated microorganisms are potential pathogens according to 
Fig. 4 Mean concentration ( $\pm 1 \mathrm{SD}$ ) of particular dust fraction in the air in tested institutions including internal (office) background. Number if samples $(N=12-24)$. PM2.5respirable dust with a diameter less than $2.5 \mu \mathrm{m}$; PM10_particulate matter with a diameter less than $10 \mu \mathrm{m}$ (mouth and nose)
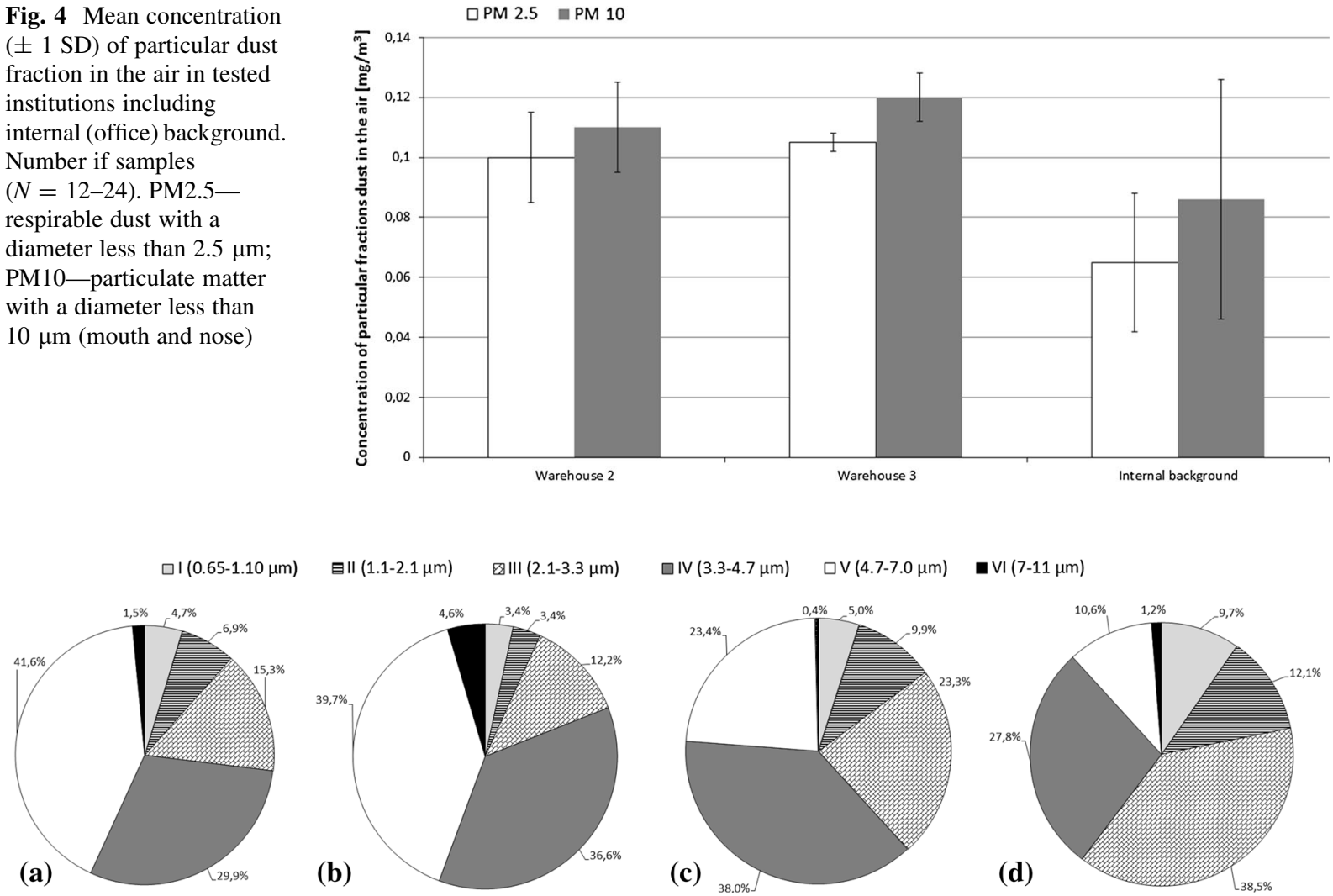

(d)

Fig. 5 Percentage contribution of each size fraction (aerodynamic diameter I-VI) of fungal bioaerosol. a Warehouse 2 in Museum II; b warehouse 3 in Museum II; c internal background (office); $\mathbf{d}$ external background (outdoors). Number of samples ( $\mathrm{N}=6$ )

classifications of the Directive UE 2000/54/WE, Regulation of the Minister of Health in Poland dated 22 April 2005, the European Confederation of Medical Mycology (BSL) and the Institute of Rural Health in Lublin (IMW). These belong to the genera: Bacillius, Pseudomonas, Alternaria, Aureobasidium, Aspergillus, Chaetomium, Chrysonilia, Cryptococcus, Cladosporium, Paecilomyces, Mucor, Penicillium, Talaromyces and Trichoderma (Table 2).

\section{Discussion}

The buildings studied differed from each other in air contamination levels, which may be due to specific features and the condition of housed collections. Tested institutions had similar levels of surface microbial contamination (furniture, walls, stored objects). The levels of microbiological contamination in all institutions studied were lower than the threshold values of occupational exposure specified by the Polish Committee for the Highest Permissible Concentrations and Intensities of Noxious Agents at the Workplace, which is $5.0 \times 10^{4} \mathrm{cfu} / \mathrm{m}^{3}$ for the total fungal count (Skowroń and Górny 2012).

We found lower or similar microbial contamination in archives compared to previous studies (Borrego et al. 2010; Karbowska-Berent et al. 2011) and higher contamination in libraries and museums (Camuffo et al. 2001; Niesler et al. 2010; Karbowska-Berent et al. 2011).

Low ergosterol levels $\left(0.41-0.69 \mathrm{ng} / \mathrm{m}^{3}\right)$ in the air of studied rooms confirmed observations made by Gutarowska et al. (2014) for rooms with low fungal contamination. An ergosterol concentration above $1 \mathrm{ng}$ per $\mathrm{m}^{3}$ can be considered as an indicator of excessive mould contamination of indoor air $\left(10^{3} \mathrm{cfu} /\right.$ $\mathrm{m}^{3}$ ) (Gutarowska et al., 2014). Our study found a significant correlation between the number of fungi in the air of museums and archives and ergosterol 
Table 2 Isolated species and frequency of their isolation in the air and on the surfaces in the examined institutions

\begin{tabular}{|c|c|c|c|c|c|c|c|c|}
\hline \multirow[t]{2}{*}{ Micro-organism } & \multicolumn{8}{|c|}{$\begin{array}{l}\text { Frequency of isolation of all samples in each institution [\%] } \\
\text { Air/surfaces }\end{array}$} \\
\hline & $\begin{array}{l}\text { Museum } \\
\text { I }\end{array}$ & $\begin{array}{l}\text { Museum } \\
\text { II }\end{array}$ & $\begin{array}{l}\text { Museum } \\
\text { III }\end{array}$ & $\begin{array}{l}\text { Museum } \\
\text { IV }\end{array}$ & $\begin{array}{l}\text { Archive } \\
\text { I }\end{array}$ & $\begin{array}{l}\text { Archive } \\
\text { II }\end{array}$ & $\begin{array}{l}\text { Library } \\
\text { I }\end{array}$ & $\begin{array}{l}\text { Library } \\
\text { II }\end{array}$ \\
\hline \multicolumn{9}{|l|}{ Bacteria } \\
\hline $\begin{array}{l}\text { Aneurinibacillus } \\
\text { aneurinilyticus }\end{array}$ & $0 / 0$ & $0 / 0$ & $0 / 0$ & $0 / 0$ & $0 / 0$ & $0 / 0$ & $0 / 0$ & $0 / 33.3$ \\
\hline Bacillus circulans & $0 / 0$ & $0 / 0$ & $0 / 0$ & $0 / 0$ & $0 / 0$ & $0 / 0$ & $22.2 / 0$ & $0 / 0$ \\
\hline Bacillus firmus & $75.0 / 0$ & $0 / 0$ & $0 / 0$ & $0 / 0$ & $0 / 0$ & $0 / 0$ & $0 / 0$ & $0 / 0$ \\
\hline Bacillus licheniformis & $0 / 0$ & $0 / 0$ & $0 / 0$ & $0 / 0$ & $0 / 0$ & $21.4 / 0$ & $0 / 0$ & $8.3 / 33.3$ \\
\hline Bacillus megaterium & $0 / 0$ & $0 / 0$ & $0 / 58.3$ & $0 / 0$ & $0 / 41.7$ & $0 / 0$ & $0 / 0$ & $0 / 0$ \\
\hline Bacillus mycoides & $0 / 0$ & $0 / 0$ & $0 / 0$ & $0 / 0$ & $0 / 0$ & $0 / 0$ & $0 / 80$ & $0 / 0$ \\
\hline Bacillus pumilus & $0 / 55.0$ & $0 / 0$ & $0 / 75.0$ & $0 / 62.5$ & $0 / 0$ & $21.4 / 26.3$ & $0 / 45$ & $8.3 / 0$ \\
\hline Bacillus sp. & $0 / 66.7$ & $0 / 0$ & $0 / 0$ & $0 / 0$ & $0 / 0$ & $0 / 0$ & $0 / 0$ & $0 / 0$ \\
\hline Bacillus subtilis & $0 / 44.4$ & $0 / 0$ & $0 / 66.7$ & $0 / 0$ & $0 / 0$ & $21.4 / 10.5$ & $0 / 0$ & $33.3 / 33.3$ \\
\hline Brevibacillus laterosporus & $0 / 50.0$ & $0 / 0$ & $0 / 0$ & $0 / 0$ & $0 / 0$ & $0 / 0$ & $0 / 0$ & $0 / 0$ \\
\hline Kocuria kristinae & $0 / 0$ & $0 / 0$ & $0 / 0$ & $0 / 0$ & $0 / 0$ & $0 / 0$ & $22.2 / 0$ & $0 / 0$ \\
\hline Kocuria varians/rosea & $75.0 / 0$ & $0 / 0$ & $0 / 0$ & $0 / 0$ & $0 / 0$ & $0 / 0$ & $0 / 0$ & $0 / 0$ \\
\hline Lactobacillus delbrueckii & $0 / 50.0$ & $0 / 50.0$ & $0 / 0$ & $0 / 0$ & $0 / 0$ & $0 / 0$ & $0 / 0$ & $0 / 0$ \\
\hline Leuconostoc mesenteroides & $0 / 0$ & $0 / 0$ & $0 / 0$ & $0 / 0$ & $61.1 / 0$ & $0 / 0$ & $0 / 0$ & $0 / 0$ \\
\hline Micrococcus flavus & $0 / 0$ & $0 / 0$ & $0 / 0$ & $0 / 0$ & $0 / 0$ & $92.9 / 0$ & $0 / 0$ & $0 / 0$ \\
\hline Micrococcus sp. & $95.9 / 83.3$ & $100.0 / 0$ & $86.1 / 16.7$ & $95.9 / 56.3$ & $100 / 41.7$ & $0 / 0$ & $66.7 / 0$ & $100 / 0$ \\
\hline Micromonospora sp. & $0 / 0$ & $0 / 0$ & $0 / 0$ & $0 / 0$ & $0 / 0$ & $0 / 26.3$ & $0 / 0$ & $0 / 0$ \\
\hline Nocardia sp. & $0 / 0$ & $0 / 0$ & $0 / 0$ & $0 / 0$ & $0 / 0$ & $21.4 / 0$ & $0 / 0$ & $41.7 / 0$ \\
\hline Paenibacillus polymyxa & $0 / 0$ & $0 / 0$ & $0 / 91.7$ & $0 / 0$ & $0 / 0$ & $0 / 0$ & $0 / 0$ & $0 / 0$ \\
\hline Pseudomonas alcaligenes & $0 / 0$ & $75.0 / 0$ & $0 / 0$ & $0 / 0$ & $0 / 0$ & $0 / 0$ & $22.2 / 0$ & $0 / 0$ \\
\hline Pseudomonas stutzeri & $0 / 0$ & $0 / 0$ & $0 / 0$ & $0 / 0$ & $0 / 0$ & $0 / 0$ & $27.8 / 0$ & $0 / 0$ \\
\hline Pseudomonas oryzyhabitans & $0 / 0$ & $0 / 0$ & $0 / 0$ & $0 / 0$ & $38.9 / 0$ & $0 / 0$ & $0 / 0$ & $0 / 0$ \\
\hline Sphingomonas paucimobilis & $0 / 0$ & $0 / 0$ & $0 / 0$ & $0 / 50.0$ & $0 / 0$ & $0 / 0$ & $0 / 0$ & $0 / 0$ \\
\hline Staphylococcus haemolyticus & $0 / 0$ & $0 / 0$ & $100.0 / 0$ & $0 / 0$ & $0 / 0$ & $0 / 0$ & $0 / 0$ & $0 / 0$ \\
\hline Staphylococcus cohnii & $0 / 0$ & $0 / 0$ & $0 / 0$ & $0 / 0$ & $94.4 / 0$ & $0 / 0$ & $0 / 0$ & $0 / 0$ \\
\hline Staphylococcus hominis & $91.7 / 0$ & $0 / 0$ & $0 / 0$ & $0 / 0$ & $0 / 0$ & $0 / 0$ & $0 / 0$ & $0 / 0$ \\
\hline Staphylococcus lentus & $0 / 0$ & $100.0 / 0$ & $0 / 0$ & $0 / 0$ & $0 / 0$ & $0 / 26.3$ & $100 / 0$ & $66.7 / 0$ \\
\hline Staphylococcus xylosus & $75.0 / 0$ & $0 / 0$ & $0 / 0$ & $0 / 0$ & $0 / 0$ & $0 / 21$ & $0 / 0$ & $33.3 / 0$ \\
\hline \multicolumn{9}{|l|}{ Fungi } \\
\hline Acremonium furcatum & $0 / 0$ & $0 / 0$ & $0 / 0$ & $0 / 0$ & $5.6 / 0$ & $0 / 0$ & $0 / 0$ & $0 / 0$ \\
\hline Acremonium verticillium & $0 / 0$ & $0 / 0$ & $0 / 0$ & $0 / 0$ & $0 / 0$ & $0 / 0$ & $11.1 / 0$ & $0 / 0$ \\
\hline Alternaria alternata & $0 / 14.3$ & $0 / 0$ & $0 / 0$ & $0 / 43.8$ & $0 / 0$ & $7.1 / 0$ & $0 / 35$ & $0 / 0$ \\
\hline Alternaria consortiale & $0 / 14.3$ & $0 / 0$ & $0 / 0$ & $0 / 0$ & $0 / 0$ & $0 / 0$ & $5.6 / 0$ & $16.7 / 0$ \\
\hline Alternaria sp. & $0 / 0$ & $0 / 0$ & $0 / 0$ & $0 / 0$ & $0 / 0$ & $14.3 / 0$ & $0 / 0$ & $0 / 0$ \\
\hline Alternaria tennuissima & $0 / 0$ & $0 / 0$ & $0 / 0$ & $0 / 0$ & $0 / 0$ & $0 / 0$ & $33.3 / 15$ & $0 / 0$ \\
\hline Aspergillus clavatus & $0 / 0$ & $0 / 0$ & $0 / 0$ & $0 / 0$ & $0 / 0$ & $0 / 0$ & $5.6 / 0$ & $0 / 0$ \\
\hline Aspergillus flavus & $0 / 0$ & $0 / 0$ & $0 / 0$ & $0 / 12.5$ & $0 / 0$ & $0 / 0$ & $0 / 0$ & $0 / 12.5$ \\
\hline Aspergillus fumigatus & $0 / 0$ & $0 / 0$ & $0 / 0$ & $0 / 0$ & $0 / 0$ & $7.1 / 0$ & $0 / 0$ & $0 / 0$ \\
\hline Aspergillus niger & $20.8 / 28.6$ & $0 / 12.5$ & $0 / 0$ & $4.2 / 0$ & $0 / 0$ & $7.1 / 0$ & $16.7 / 15$ & $8.3 / 0$ \\
\hline Aspergillus ochraceus & $0 / 0$ & $0 / 0$ & $0 / 0$ & $8.3 / 0$ & $0 / 0$ & $0 / 0$ & $0 / 15$ & $0 / 0$ \\
\hline
\end{tabular}


Table 2 continued

\begin{tabular}{|c|c|c|c|c|c|c|c|c|}
\hline \multirow[t]{2}{*}{ Micro-organism } & \multicolumn{8}{|c|}{$\begin{array}{l}\text { Frequency of isolation of all samples in each institution [\%] } \\
\text { Air/surfaces }\end{array}$} \\
\hline & $\begin{array}{l}\text { Museum } \\
\text { I }\end{array}$ & $\begin{array}{l}\text { Museum } \\
\text { II }\end{array}$ & $\begin{array}{l}\text { Museum } \\
\text { III }\end{array}$ & $\begin{array}{l}\text { Museum } \\
\text { IV }\end{array}$ & $\begin{array}{l}\text { Archive } \\
\text { I }\end{array}$ & $\begin{array}{l}\text { Archive } \\
\text { II }\end{array}$ & $\begin{array}{l}\text { Library } \\
\text { I }\end{array}$ & $\begin{array}{l}\text { Library } \\
\text { II }\end{array}$ \\
\hline Aspergillus parasiticus & $0 / 0$ & $0 / 0$ & $0 / 27.3$ & $0 / 0$ & $0 / 0$ & $0 / 0$ & $0 / 0$ & $0 / 0$ \\
\hline Aspergillus puulaaensis & $25.0 / 0$ & $0 / 50.0$ & $61.1 / 0$ & $4.2 / 0$ & $0 / 0$ & $14.3 / 11.1$ & $0 / 0$ & $58.3 / 0$ \\
\hline Aspergillus terreus & $0 / 0$ & $0 / 0$ & $0 / 0$ & $12.5 / 0$ & $0 / 0$ & $0 / 0$ & $0 / 0$ & $0 / 0$ \\
\hline Aspergillus wentii & $0 / 0$ & $0 / 0$ & $0 / 0$ & $8.3 / 0$ & $0 / 0$ & $0 / 0$ & $0 / 0$ & $0 / 0$ \\
\hline Aureobasidium pullulans & $0 / 0$ & $0 / 0$ & $0 / 0$ & $4.2 / 0$ & $0 / 0$ & $0 / 0$ & $0 / 0$ & $0 / 0$ \\
\hline Beauveria sp. & $0 / 0$ & $0 / 0$ & $0 / 0$ & $0 / 0$ & $11.1 / 0$ & $0 / 0$ & $0 / 0$ & $0 / 0$ \\
\hline Botrytis cinerea & $0 / 0$ & $0 / 0$ & $0 / 0$ & $0 / 0$ & $5.6 / 0$ & $0 / 0$ & $16.7 / 0$ & $0 / 0$ \\
\hline Botrytis sp. & $4.2 / 0$ & $0 / 0$ & $0 / 0$ & $0 / 0$ & $0 / 0$ & $7.1 / 0$ & $0 / 0$ & $8.3 / 0$ \\
\hline Chaetomium globosum & $0 / 0$ & $0 / 0$ & $0 / 0$ & $0 / 0$ & $0 / 0$ & $0 / 0$ & $0 / 10$ & $0 / 0$ \\
\hline Chrysonilia sitophila & $0 / 0$ & $0 / 0$ & $0 / 0$ & $0 / 0$ & $38.9 / 0$ & $21.4 / 0$ & $0 / 0$ & $0 / 0$ \\
\hline Cladosporium cladosporioides & $0 / 0$ & $0 / 12.5$ & $38.9 / 0$ & $0 / 12.5$ & $16.7 / 12.5$ & $14.3 / 33.3$ & $72.2 / 35$ & $58.3 / 0$ \\
\hline Cladosporium herbarum & $0 / 0$ & $0 / 0$ & $50.0 / 0$ & $16.7 / 18.8$ & $72.2 / 0$ & $7.1 / 0$ & $0 / 30$ & $58.3 / 0$ \\
\hline Cladosporium sp. & $4.2 / 0$ & $0 / 0$ & $0 / 0$ & $0 / 0$ & $0 / 0$ & $0 / 0$ & $0 / 0$ & $0 / 0$ \\
\hline Epicoccum nigrum & $0 / 0$ & $0 / 0$ & $0 / 0$ & $0 / 0$ & $0 / 0$ & $0 / 0$ & $16.7 / 0$ & $0 / 0$ \\
\hline Eurotium amstelodami & $0 / 0$ & $0 / 0$ & $0 / 0$ & $0 / 0$ & $0 / 0$ & $0 / 0$ & $0 / 25$ & $0 / 0$ \\
\hline Gliocladium sp. & $0 / 0$ & $0 / 0$ & $0 / 0$ & $0 / 0$ & $0 / 0$ & $0 / 0$ & $5.6 / 0$ & $0 / 0$ \\
\hline Mucor circinelloides & $0 / 0$ & $0 / 0$ & $0 / 0$ & $0 / 6.3$ & $0 / 0$ & $0 / 0$ & $0 / 10$ & $0 / 12.5$ \\
\hline Mucor globosus & $0 / 0$ & $0 / 0$ & $0 / 0$ & $0 / 0$ & $0 / 0$ & $0 / 0$ & $0 / 0$ & $8.3 / 0$ \\
\hline Mucor hiemalis & $8.3 / 0$ & $0 / 0$ & $0 / 0$ & $0 / 0$ & $0 / 0$ & $0 / 0$ & $0 / 0$ & $0 / 0$ \\
\hline Mucor plumbeus & $0 / 0$ & $0 / 0$ & $0 / 18.9$ & $0 / 0$ & $0 / 0$ & $0 / 0$ & $0 / 0$ & $0 / 0$ \\
\hline Mucor racemosus & $0 / 14.3$ & $0 / 0$ & $0 / 18.9$ & $0 / 0$ & $0 / 0$ & $0 / 0$ & $0 / 0$ & $0 / 0$ \\
\hline Mucor sp. & $0 / 0$ & $0 / 0$ & $0 / 0$ & $0 / 0$ & $0 / 0$ & $0 / 0$ & $0 / 0$ & $8.3 / 0$ \\
\hline Paecilomyces variotii & $0 / 0$ & $0 / 0$ & $0 / 0$ & $0 / 31.3$ & $0 / 0$ & $0 / 44.4$ & $0 / 0$ & $0 / 0$ \\
\hline Penicillium griseofulvum & $0 / 0$ & $0 / 0$ & $0 / 0$ & $0 / 0$ & $0 / 0$ & $0 / 0$ & $11.1 / 0$ & $0 / 0$ \\
\hline Penicillium chrysogenum & $0 / 7.1$ & $0 / 25.0$ & $0 / 0$ & $8.3 / 18.8$ & $0 / 0$ & $0 / 0$ & $27.7 / 20$ & $0 / 0$ \\
\hline Penicillium commune & $0 / 0$ & $0 / 0$ & $0 / 0$ & $0 / 0$ & $0 / 0$ & $0 / 0$ & $16.7 / 0$ & $0 / 0$ \\
\hline Penicillium corylophilum & $0 / 0$ & $0 / 0$ & $0 / 27.3$ & $25.0 / 18.8$ & $0 / 0$ & $0 / 0$ & $0 / 0$ & $8.3 / 0$ \\
\hline Penicillium crustosum & $45.8 / 57.1$ & $0 / 12.5$ & $5.6 / 36.4$ & $0 / 0$ & $0 / 0$ & $28.6 / 11.1$ & $33.3 / 0$ & $33.3 / 50$ \\
\hline Penicillium freii & $0 / 0$ & $0 / 0$ & $0 / 0$ & $0 / 0$ & $61.1 / 0$ & $21.4 / 33.3$ & $0 / 0$ & $50 / 25$ \\
\hline Penicillium gladioli & $0 / 0$ & $0 / 0$ & $0 / 0$ & $20.8 / 0$ & $0 / 0$ & $0 / 0$ & $0 / 0$ & $0 / 0$ \\
\hline Penicillium hirsutum & $0 / 0$ & $0 / 0$ & $0 / 0$ & $0 / 0$ & $5.6 / 0$ & $0 / 0$ & $0 / 0$ & $0 / 0$ \\
\hline Penicillium janthinellum & $0 / 0$ & $0 / 0$ & $0 / 0$ & $4.2 / 62.5$ & $0 / 0$ & $14.3 / 11.1$ & $0 / 0$ & $0 / 0$ \\
\hline Penicillium olsonii & $0 / 0$ & $0 / 0$ & $0 / 0$ & $0 / 0$ & $0 / 25.3$ & $0 / 0$ & $0 / 0$ & $0 / 0$ \\
\hline Penicillium oxalicum & $0 / 0$ & $0 / 0$ & $0 / 0$ & $0 / 0$ & $5.6 / 0$ & $0 / 0$ & $0 / 0$ & $0 / 0$ \\
\hline Penicillium radicola & $45.8 / 0$ & $0 / 0$ & $0 / 0$ & $0 / 0$ & $0 / 0$ & $0 / 0$ & $0 / 0$ & $0 / 0$ \\
\hline Penicillium sclerotigenum & $0 / 0$ & $0 / 0$ & $0 / 0$ & $8.3 / 0$ & $0 / 0$ & $0 / 0$ & $0 / 0$ & $0 / 0$ \\
\hline Penicillium viridicatum & $0 / 0$ & $0 / 0$ & $0 / 0$ & $0 / 0$ & $16.7 / 0$ & $0 / 0$ & $0 / 0$ & $0 / 0$ \\
\hline Penicillium waksmanii & $0 / 0$ & $0 / 0$ & $0 / 0$ & $0 / 0$ & $0 / 0$ & $0 / 0$ & $55.6 / 0$ & $0 / 0$ \\
\hline Rhizopus oryzae & $37.5 / 14.3$ & $100 / 0$ & $27.8 / 0$ & $0 / 0$ & $38.9 / 56.3$ & $14.3 / 0$ & $0 / 0$ & $0 / 12.5$ \\
\hline Talaromyces wartmannii & $0 / 0$ & $0 / 0$ & $0 / 0$ & $0 / 0$ & $0 / 0$ & $0 / 0$ & $0 / 10$ & $0 / 0$ \\
\hline Trichoderma koningii & $0 / 0$ & $0 / 0$ & $0 / 0$ & $0 / 0$ & $0 / 0$ & $0 / 0$ & $22.2 / 20$ & $0 / 0$ \\
\hline Trichoderma viride & $0 / 0$ & $0 / 0$ & $5.6 / 0$ & $0 / 0$ & $0 / 0$ & $0 / 0$ & $0 / 25$ & $0 / 0$ \\
\hline
\end{tabular}


Table 2 continued

\begin{tabular}{|c|c|c|c|c|c|c|c|c|}
\hline \multirow[t]{2}{*}{ Micro-organism } & \multicolumn{8}{|c|}{$\begin{array}{l}\text { Frequency of isolation of all samples in each institution [\%] } \\
\text { Air/surfaces }\end{array}$} \\
\hline & $\begin{array}{l}\text { Museum } \\
\text { I }\end{array}$ & $\begin{array}{l}\text { Museum } \\
\text { II }\end{array}$ & $\begin{array}{l}\text { Museum } \\
\text { III }\end{array}$ & $\begin{array}{l}\text { Museum } \\
\text { IV }\end{array}$ & $\begin{array}{l}\text { Archive } \\
\text { I }\end{array}$ & $\begin{array}{l}\text { Archive } \\
\text { II }\end{array}$ & $\begin{array}{l}\text { Library } \\
\text { I }\end{array}$ & $\begin{array}{l}\text { Library } \\
\text { II }\end{array}$ \\
\hline Ulocladium sp. & $0 / 0$ & $0 / 0$ & $0 / 0$ & $0 / 0$ & $0 / 0$ & $0 / 0$ & $5.6 / 0$ & $0 / 0$ \\
\hline \multicolumn{9}{|l|}{ Yeast } \\
\hline Candida $\mathrm{sp}$. & $0 / 0$ & $0 / 0$ & $0 / 0$ & $0 / 31.3$ & $0 / 0$ & $0 / 0$ & $0 / 0$ & $0 / 0$ \\
\hline Candida sphaerica & $0 / 35.7$ & $0 / 0$ & $0 / 0$ & $0 / 0$ & $0 / 0$ & $0 / 0$ & $0 / 0$ & $0 / 12.5$ \\
\hline Cryptococcus humicola & $0 / 0$ & $0 / 0$ & $0 / 0$ & $0 / 0$ & $0 / 18.8$ & $0 / 0$ & $0 / 0$ & $0 / 0$ \\
\hline Cryptococcus laurentii & $0 / 0$ & $0 / 0$ & $0 / 0$ & $0 / 0$ & $0 / 0$ & $0 / 0$ & $22.2 / 0$ & $0 / 0$ \\
\hline Cryptococcus uniguttulatus & $0 / 0$ & $0 / 0$ & $0 / 0$ & $0 / 0$ & $0 / 6.3$ & $0 / 0$ & $0 / 0$ & $0 / 0$ \\
\hline Rhodotorula sp. & $0 / 0$ & $0 / 0$ & $0 / 9.1$ & $0 / 0$ & $0 / 0$ & $0 / 11.1$ & $0 / 0$ & $0 / 0$ \\
\hline Rhodotorula minuta & $0 / 0$ & $0 / 0$ & $0 / 0$ & $0 / 6.3$ & $0 / 0$ & $0 / 0$ & $0 / 0$ & $0 / 0$ \\
\hline
\end{tabular}

Species that can constitute occupational threat according to the classification of the Directive UE 2000/54/WE, Regulation of the Minister of Health in Poland dated 22 April 2005, the European Confederation of Medical Mycology (BSL) and the Institute of Rural Health in Lublin (IMW) are bolded

concentration. Ergosterol has been recommended previously as a good chemical indicator for evaluating mould concentrations in the air (Miller and Young 1997; Pasanen et al. 1999; Robine et al. 2005). No correlations were found between the number of fungi on the surfaces and ergosterol concentrations.

Steady microclimatic parameters, temperature of $20 \pm 2{ }^{\circ} \mathrm{C}$ and relative air humidity of $50 \pm 3 \%$, are recommended for collection storage in the studied institution types (ISO 11799:2003; Schäfer 2014). The temperature in $2 / 8$ and the humidity in $7 / 8$ institutions deviated from those specified in the standard. This was probably due to the lack of ventilation and air conditioning systems. There was an effect of humidity and temperature on microbial concentration in the air in majority of the facilities tested.

The highest concentration $\left(0.38-0.39 \mathrm{mg} / \mathrm{m}^{3}\right)$ of respirable dust, with particle sizes below $4 \mu \mathrm{m}$, was recorded in the rooms of Museum III. This concentration was 2-4 times higher than the 24-h exposure limits specified in the World Health Organization recommendations (WHO 2005). Fractions with aerodynamic diameters of 1.1-2.1 $\mu \mathrm{m}$ had the highest percentage contribution in fungal aerosols sampled from museum storerooms (Museum II). Based on spore sizes of the most frequently isolated fungal species, Aspergillus (2.1-3.6 $\mu \mathrm{m})$, Penicillium $(2.8-5.0 \mu \mathrm{m})$ and Cladosporium $(2.5-7.5 \mu \mathrm{m})$, we conclude that fungi occurred as single cells, as spores or small fragments of mycelium.
Based on the dust level and particle size distribution data, the aerosol within the studied workplaces is able to penetrate the human respiratory system. This can happen via nasal and oral cavities, primary, secondary and terminal bronchi and the pulmonary bronchioles, with the solid particles present in dust acting as carriers. This may cause irritation of the mucous membranes of the nose and eyes, and an inflammatory response or allergic reactions (Kulkarni et al. 2011), in exposed employees.

Commonly detected micro-organisms in the tested institutions included: Micrococcus sp., Staphylococcus sp., Bacillus sp., Aspergillus puulaaensis, Cladosporium cladosporioides, Penicillium crustosum, Rhizopus oryzae. Previous studies by KarbowskaBerent et al. (2011), Niesler et al. (2010) have shown, inter alia, that these micro-organisms colonize museums, libraries and archival facilities.

Finally, most of the identified micro-organisms constitute an occupational threat according to the literature (Report of a Working Group on Hazardous Fungi of the European Confederation of Medical Mycology 1996; Directive UE 2000/54/WE, Regulation of the Minister of Health in Poland dated 22 April 2005, Dutkiewicz et al. 2007).

Factors such as dust concentration, diameter of fungal bioaerosol particles and the presence of potentially pathogenic micro-organisms should be taken into account in the microbiological assessment of working environments in museums, archives and 
libraries. Those factors may affect the health of workers; however, it requires further study.

\section{Conclusions}

The levels and types of micro-organisms within museums, archives and libraries were institution dependent. Micro-organism numbers within workspaces did not exceed recommended limits for occupational exposure. The concentrations of respirable and suspended dust in museum storerooms were 2-4 times higher than the WHO-recommended limits. Fungi were the dominant group of micro-organisms within tested working environments. The dominant fungal aerosol fractions had aerodynamic diameters that ranged between 1.1 and $2.1 \mu \mathrm{m}$ in museum storerooms. We found a correlation between relative humidity and temperature and microbial contamination in the air. The concentration of ergosterol in the air in museum, archive and library workplaces strongly correlates with fungal concentrations in the air.

Acknowledgments Studies were realized within the project of Polish National Center for Research and Development, no. III.B.03 "Development of principles for evaluation and prevention of hazards caused by biological agents in the working environment using indicators of microbial contamination".

Open Access This article is distributed under the terms of the Creative Commons Attribution License which permits any use, distribution, and reproduction in any medium, provided the original author(s) and the source are credited.

\section{References}

Bensch, K., Braun, U., Groenewald, J. Z., \& Crous, P. W. (2012). The genus Cladosporium. Studies in Mycology, 72(1), 1-401.

Borrego, S., Guiamet, P., Gómez de Saravia, S., Batistini, P., Garcia, M., Lavin, P., et al. (2010). The quality of air at archives and the biodeterioration of photographs. International Biodeterioration and Biodegradation, 64, 139-145.

Camuffo, D., Van Grieken, R., Busse, H. J., Sturaro, G., Valentino, A., Bernardi, A., et al. (2001). Environmental monitoring in four European museums. Atmospheric Environment, 35, 127-140.

Directive 2000/54/EC of the European Parliament and of the Council of 18 September 2000 on the protection of workers from risks related to exposure to biological agents at work,
Official Journal of the European Communities. L. 262/21, Brussels.

Dutkiewicz, J., Śpiewak, R., Jabłoński, L., \& Szymańska, J. (2007). Biological occupational risk factors. Classification, exposed occupational groups, measurement, prevention. Lublin: Ad Punctum. Polish.

Eduard, W. (2009). Fungal spores: A critical review of the toxicological and epidemiological evidence as a basis for occupational exposure limit setting. Critical Reviews in Toxicology, 39(10), 799-864.

Frisvad, J. C., \& Samson, R. A. (2004). Polyphasic taxonomy of Penicillium subgenus Penicillium. A guide to identification of food and air-borne terverticillate penicillia and their mycotoxins. Studies in Mycology, 49, 1-174.

GUS (Central Statistical Office) (2012). Branch Yearbooks. Yearbook of Labour Statistics. Warszawa: GUS

Gutarowska, B., Skóra, J., \& Pielech-Przybylska, K. (2014). Evaluation of ergosterol content in the air of various environments. Aerobiologia,. doi:10.1007/s10453-014-9344-4.

Gysels, K., Delalieux, F., Deutsch, F., Grieken, R. V., Camuffo, D., \& Bernardi, A. (2004). Indoor environment and conservation in the Royal Museum of Fine Arts, Antwerp, Belgium. Journal of Cultural Heritage, 5, 221-230.

Halstensen, A. S. (2008). Species-specific fungal DNA in airborne dust as surrogate for occupational mycotoxin exposure. International Journal of Molecular Sciences, 9, 2543-2558.

ISO 11799:2003 Information and documentation-Documents to rage requirements for archive and library materials.

Jensen, M. A., Webster, J. A., \& Straus, N. (1993). Rapid identification of bacteria on the basis polymerase chain reaction-amplified ribosomal DNA spacer polymorphisms. Applied and Environmental Microbiology, 59(4), 945-952.

Karbowska-Berent, J., Górny, R. L., Strzelczyk, A. B., \& Wlazło, A. (2011). Airborne and dust borne microorganisms in selected Polish libraries and archives. Building and Environment, 46, 1872-1879.

Klich, M. A. (2002). Identification of common Aspergillus species. Utrecht, The Netherlands: Centraalbureau voor Schimmelcultures.

Korpi, A., Järnberg, J., \& Pasanen, A.-L. (2009). Microbial volatile organic compounds. Critical Reviews in Toxicology, 39(2), 139-193.

Kulkarni, P., Baron, P. A., \& Willeke, K. (2011). Aerosol measurement: principles, techniques, and applications. New York: Wiley.

Mesquita, N., Portugal, A., Videira, S., Rodríguez-Echeverría, S., Bandeira, A. M. L., Santos, M. J. A., et al. (2009). Fungal diversity in ancient documents. A case study on the Archive of the University of Coimbra. International Biodeterioration and Biodegradation, 63, 626-629.

Miller, J. D., \& Young, J. C. (1997). The use of ergosterol to measure exposure to fungal propagules in indoor air. American Industrial Hygiene Association Journal, 58(1), 39-43.

Niesler, A., Górny, R. L., Wlazło, A., Łudzeń-Izbińska, B., Ławniczek-Wałczyk, A., Gołofit-Szymczak, M., et al. (2010). Microbial contamination of storerooms at the Auschwitz-Birkenau Museum. Aerobiologia, 26, 125-133. 
Pasanen, A. L., Yli-Pietilä, K., Pasanen, P., Kalliokoski, P., \& Tarhanen, J. (1999). Ergosterol content in various fungal species and biocontaminated building materials. Applied and Environmental Microbiology, 65(1), 138-142.

Pitt, J. I., \& Hocking, A. D. (2009). Fungi and food spoilage. London, New York: Springer, Dordrecht Heidelberg.

Regulation of the Minister of Health dated. April 22, 2005 (Journal of Laws of 2005 No. 81, item 716, as amended and Journal of Laws 2008, No. 48, item 288). Polish.

Report of a Working Group on Hazardous Fungi of the European Confederation of Medical Mycology (ECMM). Risk assessment of fungi reported from humans and animals (1996). Mycoses, 39(11-12), 407-417.

Robine, E., Lacaze, I., Moularat, S., Ritoux, S., \& Boissier, M. (2005). Characteristic of exposure to airborne fungi: Measurement of ergosterol. Journal of Microbiological Methods, 63(2), 185-192.

Schäfer, I. (2014). New Standards in Preventive Conservation Management. IFLA WLIC 2014, 16-22 August 2014, Lyon, France. conference proceedings http://library.ifla. org/1005/7/209-schafer-en.pdf Accessed 20 November 2014.

Skóra, J., Zduniak, K., Gutarowska, B., \& Rembisz, D. (2012). Harmful biological agents at museum workposts. Medycyna Pracy, 63(2), 153-165. Polish.

Skowroń, J., \& Górny, R. (2012). Harmful biological agents. In: D. Augustyńska, \& M. Pośniak, (Eds.), The Interdepartmental Commission for Maximum Admissible Concentrations and Intensities for Agents Harmful to Health in the Working Environment: limit values 2012. Warszawa: Centralny Instytut Ochrony Pracy-Państwowy Instytut Badawczy. Polish.
Stanisz, A. (2006). Approachable course of statistics based on software STATISTICA PL with examples from medicine. T.1: Basic Statistics (p. 362). StatSoft Polska, Kraków, Polish.

Stępień, Ł., Koczyk, G., \& Waśkiewicz, A. (2011). Genetic and phenotypic variation of Fusarium proliferatum isolates from different host species. Journal of Applied Genetics, $52,487-496$.

White, T. J., Bruns, T., Lee, S., \& Taylor, J. (1990). Amplification and direct sequencing of fungal ribosomal RNA genes for phylogenetic. In M. A. Innis, D. H. Gelfand, J. J. Shinsky, \& T. J. White (Eds.), The PCR Protocols: A Guide to Methods and Applications (pp. 315-322). San Diego, USA: Academic Press.

Wiszniewska, M., Walusiak-Skorupa, J., Pannenko, I., Draniak, M., \& Pałczyński, C. (2009). Occupational exposure and sensitization to fungi among museum workers. Оссираtional Medicine, 59, 237-242.

World Health Organization (WHO). (2005). Air quality guidelines for particulate matter, ozone, nitrogen dioxide and sulfur dioxide. Global update. Germany: Druckpartner Moser.

Zhang, Z., Schwartz, S., Wagner, L., \& Miller, W. (2000). A greedy algorithm for aligning DNA sequences. Journal of Computational Biology, 7(1-2), 203-214.

Zielińska-Jankiewicz, K., Kozajda, A., Piotrowska, M., \& Szadkowska-Stańczyk, I. (2008). Microbiological contamination with moulds in work environment in libraries and archive storage facilities. Annals of Agricultural and Environmental Medicine, 15, 71-78. 